\title{
矩形管路内の微小傾斜面を持つ静止板に働く横流体力を利用した 流量計の基本特性改善と性能評価*
}

\author{
一 柳 隆 義*1, 西 海 孝 夫*1 \\ Evaluation and Improvement of Basic Characteristics on \\ the Flowmeter Utilizing Lateral Flow Force Acted on \\ the Stationary Plate with Minute Slope in a Rectangular Fluid Line
}

\author{
Takayoshi ICHIYANAGI*2 and Takao NISHIUMI \\ ${ }^{* 2}$ Department of Mechanical Systems Engineering, School of Systems Engineering, National Defense Academy, \\ 1-10-20 Hashirimizu, Yokosuka-shi, Kanagawa, 239-8686 Japan
}

\begin{abstract}
In the previous research, the authors have been proposed a unique flowmeter, which utilizes a lateral flow force generated on the plate with minute slope in a rectangular flow line. In the previous works, the test flowmeter was investigated experimentally to confirm the torque versus flow characteristics. Although the results showed expected performance in terms of linearity and repeatability, the deviation between the experimental and analytical results occurred on the high flow rate condition. Then the theoretical analysis using the CFD approach was conducted to obtain the detailed information of the flow behavior inside the flowmeter. It was found that one of the reasons for this deviation was caused by the remarkable pressure drop and flow disturbance at the inlet region of the flowmeter. In this paper, in order to improve the performance of the present flowmeter, the revised configuration of the flowmeter is proposed. Basic static characteristics are studied experimentally including the measurement of pressure distribution inside the flowmeter to verify the performance of the revised configuration. In addition, the dynamic characteristics are also investigated and compared with commercial flowmeters.
\end{abstract}

Key Words: Flowmeter, Flow Force, Pipe Flow, Pressure Distribution, Viscous Flow, Hydraulic System

\section{1. 緒言}

流量計測は，測定目的，環境，用途に応じて多種多様な 構造や原理を有しており，古くから様々な流量計が開発さ れている(1)(4). 著者らは, 液体用の流量計測手法として, 管 路内に受圧体と呼ぶ微小攧斜面を持つ静止板を置き，その 受圧体の両面に働く圧力差により発生するモーメントをひ ずみ式トルク変換器で測定し, これを流量に変換して求め る力法を考案している(の).この流量測定法は，そもそも油圧 制御弁に㧍い, スプール軸がスリーブに片当たりの接触 を起こし, 作動不良の)原因となる流体固着現彖のから発想を 得たものである. すなわち, 提案する本流量計の原理は, 流れ力向に沿って中央が細、テーパ形状の受圧体を管路中 心に対して水平方向に偏心させて置くとき, 流れに垂直方 向に流体力か溌生することを積極的に利用している.この 横流体力は，受圧体中心回りのトルクを検出することによ

\footnotetext{
* 原稿受付 2007 年 6 月 5 日.

*1 正員, 防衛大学校システム工学群機械システム工学科 (画 239-8686 横須賀市走水 1-10-20).

E-mail : ichiyana@nda.ac.jp
}

って流量に変換される. このように本流量計は, 微小な圧 力差を比䡈的に広い受圧面で受け堌幅させ, 静止トルクと して検出するため, 既存の流軎計に比べ, 部品数が少なく, 機構が単純で, 可動部が存在せず, 圧力損失が小さいとい う特徴を有しており，汎用性のある流量計として期待でき る.

本流量計に関しては，すでに，受圧体が矩形と円形の場 合について, 二次元層流粘性流れにもとづく理論から流量 と発生トルクとの関係式を導き, 受圧体の流路や偏心量な どの諸元や寸法を決定するための設計指針を確立した．さ らに, 流量と発生トルクとの関㐿式からゲイン保数を理論 的に求め, 円形型に比べて矩形型の優位性を明らかれする とともに，矩形型流量計を設計試作し，通過流量に対する 検出トルクの静特性計測から小流量の条件下で本流量計の 性能を確認した. しかしながら，前報て試作した流量計は， 高流量域において，流量・トルク特性力理論值に対して大 きな差異を生じたこと，低流領域でもこの特性が粘度条件 に依存して変化してしまうことなど, 本流量計を実用化す る上では，流量・トルク特性の改善をはじめとする様々な 性能の向上を図る必要があった. 
そこで，本研究では，ます既存の両側傾斜面の受圧体を 片傊だけ平面に形状変更すると同時に, 受圧体の入出口部 に整流用のブロックを設置して助走区間を設け, ゲインの 安定性と直線性を確保する。つぎに，流量計の工業的な有 用性を見極めるために, 作動油の温度変化を考慮に入れ流 量を実時間演算するシステムを構築して，その性能を評価 する. さらに, 本流量計の周波数觉答を計測し，市販され ている 2 台の流量計の動特性との比較により，瞬时流量計 としての可能性を検証する.

\section{2. 主な記号の説明}

本論文で使用する主な記号は以下の通りである.

$$
\begin{array}{ll}
a & : \text { 受圧体の幅 } \\
b & : \text { 受圧体の高さ } \\
C & : \text { 補正係数 } \\
e & : \text { 流路中心からの受圧体の } y \text { 軸方向偏心量 } \\
\bar{e} & : y \text { 軸方向の無次元偏心量 } \bar{e}=e / h_{i} \\
h & : \text { 流量計の流路のすきま } \\
\bar{h} & : \text { すきま比 } \bar{h}=h_{o} / h_{i} \\
h_{i} & : \text { 流量計入出口部の平均すきま } \\
h_{o} & : \text { 傾斜面における中央部の平均すきま } \\
K & : \text { 算出流量係数 } \\
L_{e} & : \text { 助走区間 } \\
l & : \text { 受圧体の全長 } \\
P & : \text { 圧力 } \\
\Delta \bar{P} & : \text { 無次元圧力差 } \quad \Delta \bar{P}=\left(P_{L}-P_{R}\right) /\left(P_{1}-P_{2}\right) \\
Q & : \text { 流量 } \\
Q_{r e f} & : \text { 基淮流量計における流量 } \\
T & : \text { 水ク } \\
x & : \text { 受圧体中心 } \mathrm{O} \text { 点からの距離 } \\
\bar{x} & : \text { 無次元距離 } \bar{x}=x / l \\
\varepsilon & : \text { 流量特性倸数 } \\
\Theta & : \text { 作動油の温度 } \\
&
\end{array}
$$

$$
\begin{array}{cl}
\kappa & : \text { ゲイン係数 } \\
\mu & : \text { 作動油の粘度 } \\
\tau & : \text { 無次元トルク } \\
\text { 添え字 } & \\
1 & : \text { 流量計の上流側 } \\
2 & : \text { 流量計の下流側 } \\
i & : \text { 流量計入出口部 } \\
o & : \text { 流量計中央部 } \\
L & : \text { 受圧体の左側 } \\
R & : \text { 受圧体の右側 }
\end{array}
$$

\section{3. 流量計の構造と基礎式}

図 1 に提案する流量計の基本構造を示す。この流量 計は，矩形管路内に受圧体と呼ぶ微小傾斜面を持つ板 が設置され，この両側を流体が通過する構造となって いる. 同図のように，受圧体は矩形管路の $y$ 軸中心か

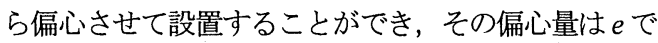
ある. また，その形状は，従来のように両面が中央に 向かって細くなる傾斜面で構成されているものを設計 変更し，流体の流れに対して左側の面を平面にしてい る.したがって，左側流路では平行二平面間を通過す るすきま流れとなり，右側流路では傾斜二平面間の寸 きま流れ（上流側では広がりすきま流れ，下流側では 狭まりすきま流れ）となる，それぞれの流路を通過す る流量は, 二次元層流粘性流れの基礎式を適用すると 以下のとおり表すことができる(7).

- 左側流路（平行流路）: $Q_{L}=Q_{L 1}=Q_{L 2}$

$$
\left.\begin{array}{c}
Q_{L 1}=\frac{b h_{L i}^{3}}{6 \mu l}\left(P_{1}-P_{L o}\right) \\
Q_{L 2}=\frac{b h_{L o}^{3}}{6 \mu l}\left(P_{L o}-P_{2}\right)
\end{array}\right\}
$$

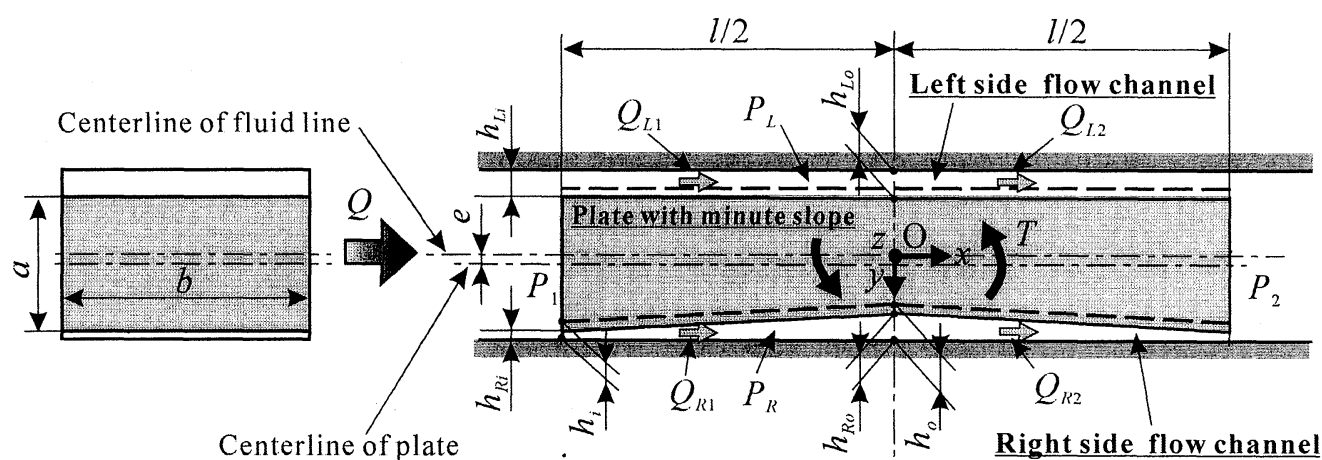

Fig. 1 Schematic diagram of flowmeter 
- 右側流路（傾斜流路）： $Q_{R}=Q_{R 1}=Q_{R 2}$

$$
\left.\begin{array}{l}
Q_{R 1}=\frac{b}{3 \mu l} \frac{\left(h_{R i} h_{R o}\right)^{2}}{h_{R i}+h_{R o}}\left(P_{1}-P_{R o}\right) \\
Q_{R 2}=\frac{b}{3 \mu l} \frac{\left(h_{R o} h_{R i}\right)^{2}}{h_{R o}+h_{R i}}\left(P_{R o}-P_{2}\right)
\end{array}\right\}
$$

流量計を通過する全流量 $Q$ は, 左右流路の流量の和か ら求めることができ，

$$
Q=Q_{L}+Q_{R}=\varepsilon \frac{b\left(P_{1}-P_{2}\right)}{6 \mu l} h_{i}^{3}
$$

となる.ここで, $h_{i}$ は左右流路の入出口端の平均すき まであり, $\varepsilon$ は流量特性係数と呼ぶ. この流量特性係 数 $\varepsilon$ は, 傾斜面における中央部での平均すきまを $h_{o}$ と すれば, すきま比 $\bar{h}=h_{o} / h_{i}$ と無次元偏心量 $\bar{e}=e / h_{i}$ と

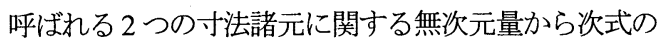
ように表すことができる.

$$
\varepsilon=\frac{(1+\bar{e})^{2}(\bar{h}+\bar{e})^{2}}{1+\bar{h}+2 \bar{e}}+\frac{(1-\bar{e})^{3}}{2}
$$

さらに, 受圧体中心 $\mathrm{O}$ 点から無次元距離 $\bar{x}=x / l$ にお いて, 受圧体の左右面が受ける圧力差は無次元化して 次式のとおり導くことができる.

$$
\begin{aligned}
\Delta \bar{P} & =\frac{P_{L}-P_{R}}{P_{1}-P_{2}} \\
& =\frac{\operatorname{sign}(\bar{x})}{2}\left\{\frac{\left(\frac{\bar{h}+\bar{e}}{\bar{h}+\bar{e}-2 \operatorname{sign}(\bar{x})(1-\bar{h}) \bar{x}}\right)^{2}-1}{\left(\frac{\bar{h}+\bar{e}}{1+\bar{e}}\right)^{2}-1}-2 \bar{x}\right\}
\end{aligned}
$$

この無次元圧力差 $\Delta \bar{P}$ は, 受圧体中心 $O$ 点に対称的に 分布するので，O点回りに発生するトルクは上流側流 路と下流側流路で発生するトルクの和で求まり, 発生 トルク $T$ を無次元化すれば次式で与えられる.

$$
\tau=\frac{T}{2 b l^{2}\left(P_{1}-P_{2}\right)}=\int_{0}^{1 / 2} \bar{x} \Delta \bar{P} d \bar{x}
$$

したがって, 式(3), (6)から流量 $Q$ と発生トルク $T$ の 関係を導くと次式で表すことができる.

$$
\frac{Q}{T}=\frac{1}{12 \mu \kappa}\left(\frac{h_{i}}{l}\right)^{3}
$$

上式中の， $\kappa$ をゲイン係数と呼び, 無次元トルク $\tau$ と 流量特性係数 $\varepsilon$ との比で定義される係数 $(\kappa=\tau / \varepsilon)$ で ある. なお, このゲイン係数 $は$ は, すきま比 $\bar{h}$ と無次

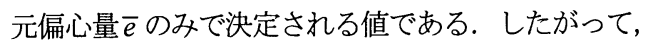

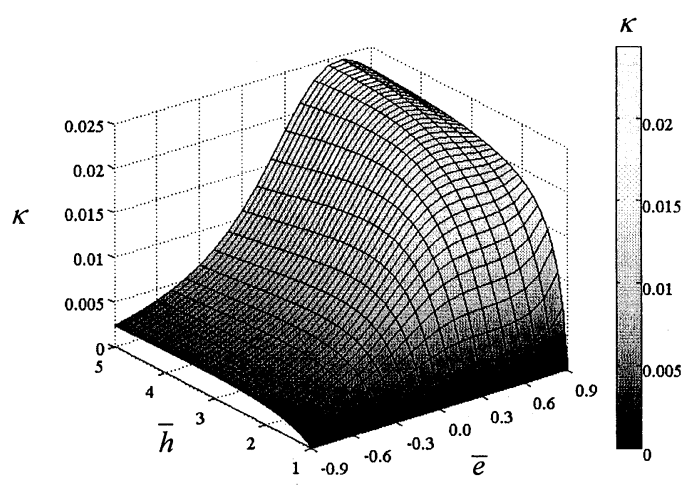

Fig. 2 Gain factor $\kappa$

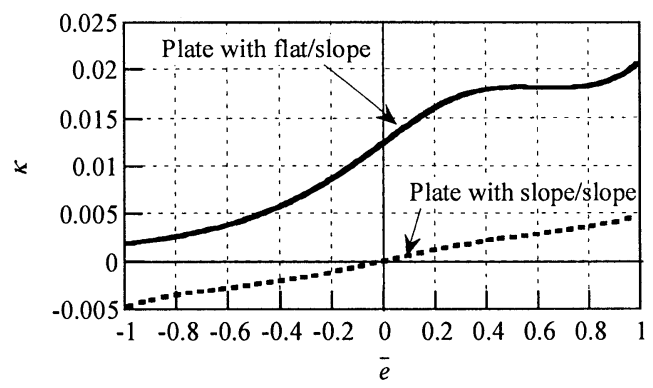

Fig. 3 Comparison of gain factor $\kappa$ with previous slope/slope type $(\bar{h}=2.0)$

流体の粘度 $\mu$ があらかじめ与えられていれば，式(7)の 右辺は定数となるので, 受圧体中心 $\mathrm{O}$ 点回りのトルク $T$ を検出することで流量 $Q$ を求めることができる.

図 2 は，すきま比 $\bar{h}(1.0 \leq \bar{h} \leq 5.0)$ と無次元偏心 量 $\bar{e}(-0.9 \leq \bar{e} \leq+0.9)$ に対するゲイン係数 $\kappa$ の関係を 示したものである. 本研究で用いる受圧体は, 片面が 平行面 (片側傾斜型受圧体と呼ぶ) であるため, 従来 の両側傾斜面 (両側傾斜型受圧体と呼ぶ) のものに比 べ, 左側流路が平行流路で構成されている. 平行流路 の圧力分布は, 流路の入口端から出口端まで直線的な 勾配となり, 雨側傾斜流路に比べて受圧体全体にわた って左右面の圧力差が高まりゲイン係数 $\kappa$ もきくな る. また, $y$ 軸において左右対称の形状を有する従来 の受圧体では, 矩形管路中央から左右方向, 寸なわち, $y$ 軸の正負方向のどちらに偏心させても特性は管路中 心軸に対して対称な特性になるのに対して, 片側傾斜 型受圧体では, 正方向と負方向の偏心で特性が異なる. たとえば, 偏心量が無、場合 $\bar{e}=0$ でも, 受圧体の左右 面が非対称であるために圧力差が生じる. 本研究では, 
受圧体を右方向に偏心させた場合（平行流路が傾斜流 路より大きくなる場合）を無次元偏心量の正方向とし た. 同図より, ゲイン係数 $\kappa$ 大きくするためには, 無次元偏心量 $\bar{゙}$ が正で,すきま比が にこれらの無次元パラメータを決定すればよいことが わかる.

図 3 は, 片側傾斜型受圧体と, 従来の両側傾斜型受

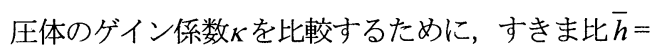
2.0 の条件における無次元偏心量 $\bar{e}$ とゲイン係数的 関係を示したものである. 同図より, 片側傾斜型受圧 体を用いた流量計のゲイン係数は, 両側傾斜型受圧体 に比べて 4 倍程度大きいことが確認できる. なお, 両 側傾斜型受圧体の場合においては, 無次元偏心量巨が 負の值にすると, 圧力差が逆方向に生じるので, ゲイ ン係数 $\kappa$ も負の值となり, 結果として受圧体中心 $\mathrm{O}$ 点 回りに生じるトルクも時計回りになる.

\section{4. 試作流量計と計測システム}

$4 \cdot 1$ 試作流量計 本研究では, 流量計の定格流量を $Q_{m x}=10 \mathrm{~L} / \mathrm{min}$, 入口側の供給圧力を $P_{1}=0.5 \sim 2.0 \mathrm{MPa}$ とし, 低圧源の油圧システムの流量を計測する目的て設計を行っ た. 使用する流体は油圧用の作動油であり ISO-VG32 (油温 $30^{\circ} \mathrm{C}$ : 粘度 $\mu=4.41 \times 10^{-2} \mathrm{Pas}$, 密度 $\left.\rho=860 \mathrm{~kg} / \mathrm{m}^{3}\right)$ と同等品を 用いる. 表 1 に，提案する試作流量計の代表的な諸元を示 す. まず, 2つの設計パラメータ $\bar{h}, \bar{e}$ の選定は, 図 2 , 図3に見るようにゲイン倸数にに大きく影響する.したがっ て, ゲイン係数火ができる限り一定の值を示す $\bar{h}>2$, $0.4 \leq \bar{e} \leq 0.6$ の範囲でこれらのパラメータ $\bar{h}=2.73$, $\bar{e}=+0.455$ を決定した. その他の寸法諸元に関しては, 流量 計の内部流路に执て十分な二次元粘性流れが得られるよ うに，矩开㧧路の綐横比を $h_{i} / b \doteqdot 1 / 30$ とし，受圧体の高さ を $b=34.8 \mathrm{~mm}$ ，入口平均すきまを $h_{i}=1.1 \mathrm{~mm}$ とした. この場 合, 左右流路内の代表レイノルス数の最大值は $Q=20 \mathrm{~L} / \mathrm{min}$ の条件でも $R e=420$ であり，十分に層流領域であることが 確涩できる. また, 受圧体の長さ $l$ は, トルク変換器の定格 值 $\left(T_{\max }=0.5 \mathrm{Nm}\right)$ を考慮し $l=70 \mathrm{~mm}$ と設計した.

$4 \cdot 2$ 計測システム 本流量計の性能評価を検証する ための計測システムの概略を図 4 に示寸. 本流㫣計の入口 側圧力は, 可変容量形ポンプの圧力補償弁によって $P_{1}=0.5 \mathrm{MPa}$ に調王した, 流量は負荷弁によって調整され， 負荷弁の下流に設置した基淮流量計（歯車式: 計測流量範 囲0.6 63L/min) で基淮流量 $Q_{\text {rg }}$ を計測した。流量計本体 (受 圧体中心O点には，負荷トルクに対してねじれ角度が極 めて小さく, 高剛性な微小トルク变換器 (ひずみ式: 定格 トルク $T_{m a x}=0.5 \mathrm{Nm}$, 分解能 $1 / 3000 \mathrm{~F} . \mathrm{S}$.) の検出軸が固定接続 されている. さらに，流路内の圧力を計測モニタするため
Table 1 Specification of proposed flowmeter

\begin{tabular}{|l|l|}
\hline Rated flow rate & $Q_{\max }=10 \mathrm{~L} / \mathrm{min}$ \\
\hline Rated torque & $T_{\max }=0.5 \mathrm{Nm}$ \\
\hline Clearance rate & $\bar{h}=2.73$ \\
\hline Non-dimensional eccentricity & $\bar{e}=0.455$ \\
\hline Inlet and outlet mean clearance & $h_{i}=1.1 \mathrm{~mm}$ \\
\hline Length of plate & $l=70 \mathrm{~mm}$ \\
\hline Width of plate & $a=33.8 \mathrm{~mm}$ \\
\hline Height of plate & $b=34.8 \mathrm{~mm}$ \\
\hline
\end{tabular}

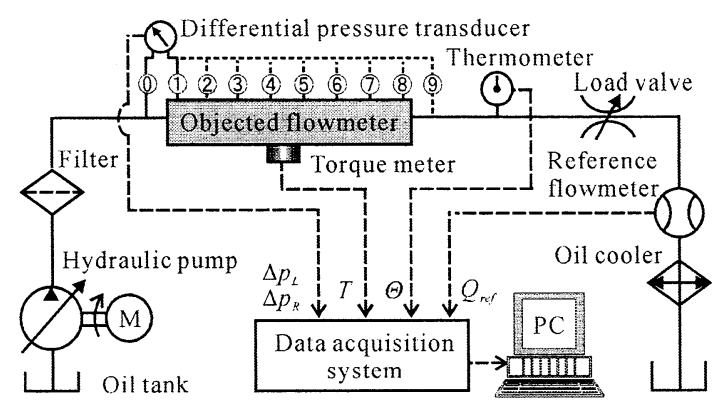

Fig. 4 Experimental apparatus

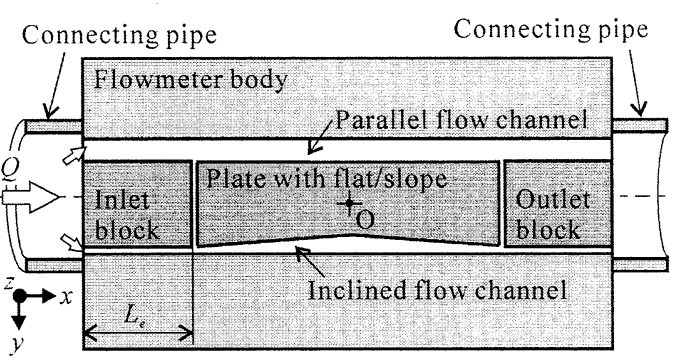

Fig. 5 Cross section of proposed flowmeter

に, 左右流路の側面に流量計入口から出口（(0)から(9) ま で10籄所のコンジット孔を設けている.それぞれの間隔は，

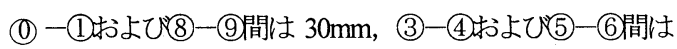
$18.5 \mathrm{~mm}$ ，中央部の(4)-(5)間は23mm であり，それ以外は寸 べて $25 \mathrm{~mm}$ とした. 左右流路内の圧力は差土変換器(ひず み式: 最大差圧 $20 \mathrm{kPa}$ ）を用いて以下のとおりに計測した. まず, 流量計入口(10での圧力を基淮圧力として差圧変換器 のポートを接続し，もう一方のポートを(1)から990各コン ジット孔に順次接続して，トルク検出と同時に基淮圧力と の各計測位置圧力との差圧，すなわち，左右各流路の圧力 分布を計測した. また, 作動油の粘度 $\mu$ を推定するために, 流量計出口端に熱電対を設置し油温計測を行っている. 以 上，すべての計測誩号は，高速 $\mathrm{AD}$ 変換器を搭載している データ解析装置により同時計測されPCに取り込まれる. 


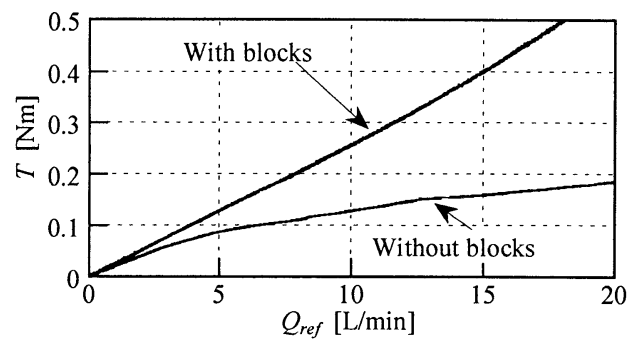

Fig. 6 Effect of inlet and outlet block $(\mu=0.0280 \mathrm{Pas})$

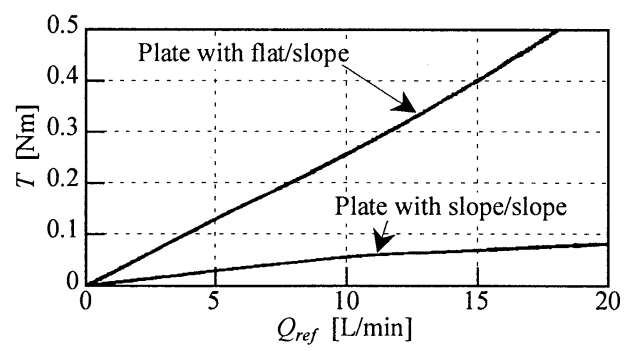

Fig. 7 Comparision of plate ( $\mu=0.0280 \mathrm{Pas})$

\section{5. 実験による性能検証}

$\mathbf{5} \cdot \mathbf{1}$ 静特性実験 本流量計の基本特性である流量 $Q$ と検出卜ルク $T$ の関係式 (式(7) は, 流量計内部流路が二 次元層流粘性流れであることを前提としている. 本研究で は，図 5 に示すような整流のためのブロック（長さ $L_{e}=60 \mathrm{~mm}$ ）を受圧体の上流側に設置し助走区間を設けた. なお，受圧体出口領域における急拡大流れの損失等を抑制 するために下流則にも同じ寸法のブロックを設置している. 図6は，助走区間の効果を調べるために基淮流量 $Q_{\text {rg }}$ と検出 トルク $T$ の関係を測定した結果である. 同図より, 助赵 間を設けない場合には， $Q_{n g}<2 \mathrm{~L} / \mathrm{min}$ 程度の低流量域までは 直線性を有しているが，それ以上の流量域ではトルクが飽 和していく傾向にある.この現象は,CFD解析の結果から， 受圧体左右流路への流入時に急縮小流れが発生し, 流体損 失を起こすことに起因していると考えられる(8). 他方, 助走 区間を設けた流量計は，トルク変換器の定格值 $T=0.5 \mathrm{Nm}$ ま て直線性を有しており，助走区間の効果が極めて高いこと が確認できる.

図 7 は，従来から提案していた両側傾斜型の受圧体と片 側㑯斜型の受圧体の形狱の違いを流量・トルク特性によっ て比較した結果である. 図 3 では, 両側傾斜型と片側頃斜

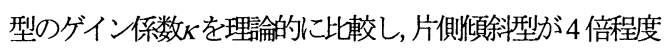
大きいことを明らかれしている. 同図より, 実験でも同様 の効果が得られることが確認できる.

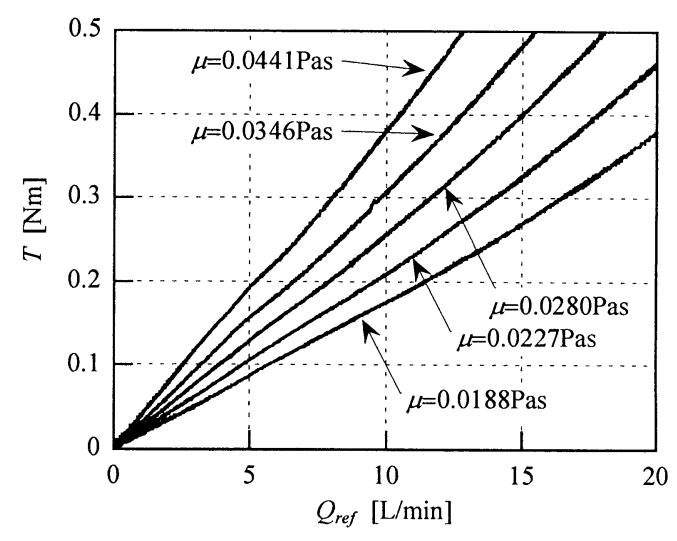

(a) Reference flow rate versus generated torque

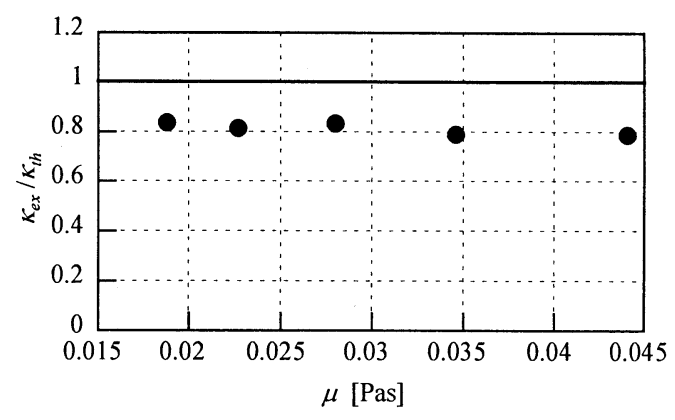

(b) Comparison with analytical value for gain factor $\kappa$

Fig. 8 Basic static characteristics

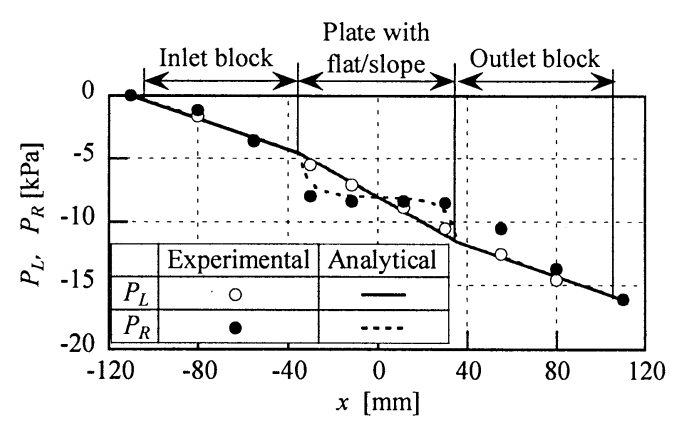

Fig. 9 Pressure distribution of proposed flowmeter ( $\left.Q_{\text {ref }}=4 \mathrm{~L} / \mathrm{min}, \mu=0.0441 \mathrm{Pas}\right)$

本流量計は, 式(7)から明らかなように, 受圧体に発 生するトルク Tだけではなく, 使用する流体の粘度 $\mu$ にも依存する特性を有している. 図 8 は, 作動油の温 度を $\Theta=35 \sim 50^{\circ} \mathrm{C}$ 範囲で $5^{\circ} \mathrm{C}$ 刻みに設定し, 粘度变化 $\left(\mu=1.88 \times 10^{-2} \sim 4.41 \times 10^{-2} \mathrm{Pas}\right)$ の影響を調べた結果で ある. 同図(a)は流量・トルク特性, (b)はゲイン係数の 設計值 $\kappa_{i h}$ と実験值 $\kappa_{e x}$ の比を流量・トルク特性から求め, 
粘度 $\mu$ との関係を示したものである．同図(a)より，本 流量計の流量・トルク特性はいずれの粘度条件におい ても, 低い流量域からトルク変換器の定格值まで高い 直線性が得られていることがわかる。 また，これらの 特性について, 実験を繰り返し行った結果, 高い再現 性を得られることも確認している. 同図(b)に見るよう に, ゲイン係数にによる設計值との比較は, 計測した すべての粘度条件でほぼ一定の值 $\left(\kappa_{e x} / \kappa_{l h} \fallingdotseq 0.8\right)$ が得 られた.このことから, 同図(a)の流量・トルク特性の 傾きが, 基本原理で述べたように作動油の粘度のみに 依存していると考えられる.

図 9 は, 流量 $Q_{r e}=4 \mathrm{~L} / \mathrm{min}$, 作動油の粘度 $\mu=4.41 \times 10^{-2}$

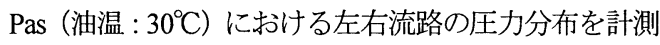
した結果である. プロットは, $-35 \mathrm{~mm}<x<+35 \mathrm{~mm}$ における圧力計測点が受圧体での分布であり， $x>+35$ $\mathrm{mm}, x<-35 \mathrm{~mm}$ は上下流ブロック (平行流路) およ び流量計入出口での計測点である. 同図より, 本流量 計内部の圧力分布 $P_{L}, P_{R}$ は, 実線 (左側平行流路) およひ破線（右側傾斜流路）で示された二次元層流粘 性流れの解析值と流量計下流部で多少の差異があるも のの, 定性的にほぼ一致している.この圧力分布から, 傾斜流路と平行流路の圧力差によって受圧体中心に卜 ルクが発生していることがわかる．また，発生する圧 力損失は, 上下流ブロックを含めても $P_{1}-P_{2}=15 \mathrm{kPa}$ 程 度であり, 基準流量計として用いた歯車式（カタログ 值 : $P_{1}-P_{2} \fallingdotseq 40 \mathrm{kPa}$ ) や浮子式 (カタログ值 : $P_{1}-P_{2} \fallingdotseq$ $230 \mathrm{kPa})$ に比べて小さいことが確認できる.

$\mathbf{5 . 2}$ 流量計としての評価 流量計の工業的な有用性

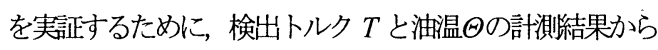
流量 $Q$ を算出し, 基淮流量計との比較により評価を行った. 本研究では，この演算をデー夕解析装置内のディジタル信 号処理器 (DSP) を利用して害時間で行っている. 演算手 順は以下のとおりである. まず, 作動油（ISO-VG32 相当） の粘度と温度の関係は，作動油メーカの物性表にもとづき， 次の近似式を作成した。

$$
\mu=19.24 \Theta^{-1.77}
$$

つぎに, 流量・トルク特性の補正に関しては図 8(b)の結 果を用いて補正係数 $C\left(=\kappa_{e x} / \kappa_{i h}\right)=0.81$ の值を決定し た.これより, 本研究で試作した流量計の演算式は以 下のとおり求められる.

$$
\begin{aligned}
Q & =f(T, \Theta)=\frac{1}{C \kappa_{t h}} \frac{1}{12 \mu}\left(\frac{h_{i}}{l}\right)^{3} T \\
& =K T \Theta 1.77
\end{aligned}
$$

ここに, $K$ を算出流量倸数と呼び, 本䒠験では $K=9.52 \times 10^{-7}$ を得た。

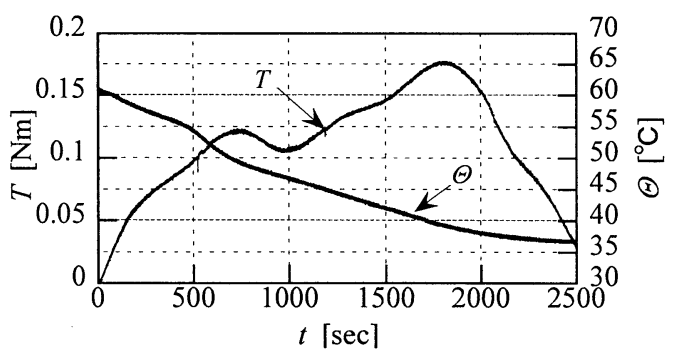

(a) Measured torque and oil temperature

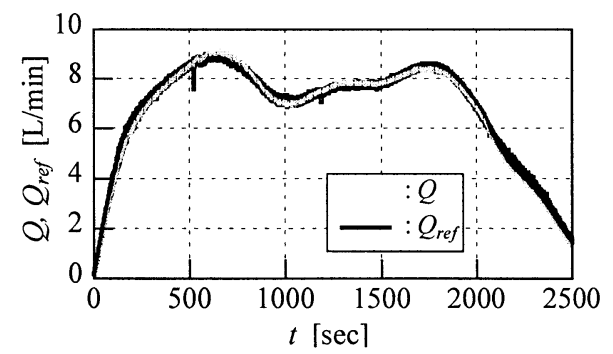

(b) Calculated flow rate $Q$ and reference flow rate $Q_{\text {ref }}$

Fig. 10 Evaluation of calculated flow rate $Q$

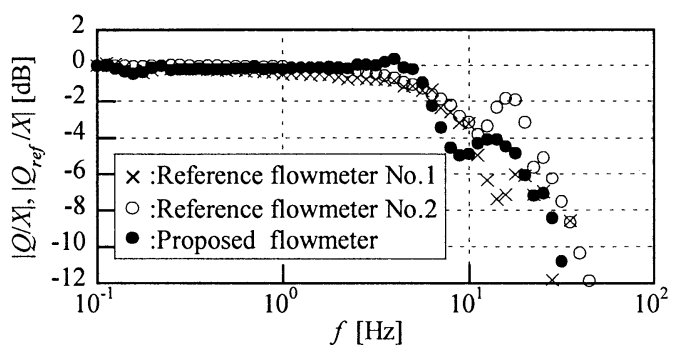

(a) Amplitude

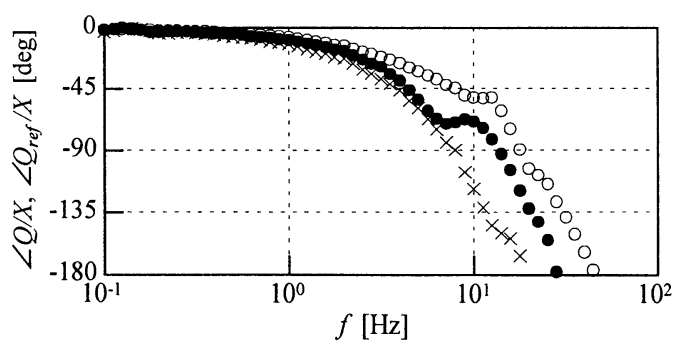

(b) Phase

Fig. 11 Frequency response of flowmeters

図 10 は, 油温を $\Theta \fallingdotseq 60^{\circ} \mathrm{C}$ 吅徐々に降下させ, 負荷バル ブによって流量を淮静的に変化させて測定を行った結果で ある. 同図(a)には，式(9)の検出トルク $T$ と油温 $を$ 示し, 
同図(b)には，実时間演算された流量 $Q$ と基淮流量 $Q_{\text {rg }}$ の比 較を約 40 分間の時刻澘にて示す。この結果から, 本流量計 によって算出された流量 $Q$ は，ほぼ全領域にわたって基淮 流量 $Q_{\text {rg }}$ 対して $\pm 3 \%$ 程度の精度で致しており, 検出卜 ルク $T$ と油温 $の$ 測定にもとづき演算すれば，流量計とし て十分に実用性があることが認められる. な押今後の研究 により, 式(8)て求めた近以式や, 式(9)の補正係数 $C$ の精度 を向上させることで, 本流量計の算出流量 $Q$ と基淮流量 $Q_{n g}$ との差異を减少させることが可能であると考える.

5.3 動特性実験 図 11 は本流量計と基淮流量計の周 波数応答を比較した結果である. 基淮流量計は, 歯車式 (No.1) と浮子式 (No.2) の2 種類であり, 両者とも市販 されている流量計では動特性に優れているものを採用した. 本研究では，動特性を計測する流量計の下流部にノズルフ ラッパー型サーボ弁を設置して正弦皮の流量入力を与えた. 周波数応答の入力は実際の変動流量に相当するサーボ弁の スプール変位 $X$ とし, 出力は, 本流量計の実時間演算流量 $Q$ と基淮流量 $Q_{\text {rg }}$ (基淮流量計 No.1， No.2）とした. 実験 条件は, 油温 $\Theta=30^{\circ} \mathrm{C}$, 流量計入口圧力 $P_{1}=1.0 \mathrm{MPa}$, サーボ 弁差压 $\Delta P_{\text {sen }}=0.8 \mathrm{MPa}$ である. 同図から, 本流量計の振幅比 がー $3 \mathrm{~dB}$ となる周波数は $f=7 \mathrm{~Hz}$ 付近であり， 2 種類の基淮 流量計は両者とも $f \fallingdotseq 10 \mathrm{~Hz}$ であることがわかる. 位相角に 関しては, 本流量計と基淮流量計No.1 が $f=6 \mathrm{~Hz}$ 付近まで同 様の傾向で遅れており, 約 $f=4.5 \mathrm{~Hz}$ でー $45^{\circ}$ となる. また, 基淮流量計 No.2 O位相角がー $45^{\circ}$ となる周波数は $f=7 \mathrm{~Hz}$ である. これらの比較より，本流量計は動特性に優れた基 準流量計とほほ同等の性能を有していることが明らかであ る.

なお，本流量計は受圧体中心 $\mathrm{O}$ 点回りのトルクを検出し ており，この慣性モーメントが, 動特性に影響を及ぼす要 因の一つとなっている. 本研究て設計した受圧体は, 開発 研究の初段皆として静特性や, 流量計内部の圧力分布など を調べことを目的としているために，比較的に大きな寸 法て設計した. したがって, 受圧体を小型化し, 受圧体中 心回りの慣性モーメントを減少させることによって, 本流 量計の動特性は，さらに向上することが期待できる.

\section{6. 結 言}

著者らは，受圧体と呼ふ微小傾斜面を持つ板を矩形管路 内に設置し，その両面に働く圧力差により発生するモ一メ ントを流量に変換する原理の新たな流量計を提案している.
本研究では，流量計の基本特性を改善し，実際面としての 流量計の工業的な有用性を評価するために種々の検証を行 った. 本報で得られた成果を以下に要約する.

(1) 既存の両側傾斜面で構成される受圧体の形状を片側だ け平行面に形状変更し, より高、流量・トルクのゲイ ン特性が得られるように改良した。

（2）流量計入出口部に整流のためのブロックを設置し助走 区間の影響を検証した，その結果，流量・トルク特性 は 0〜20L/min の領或において極めて高い直線性と再 現性が得られることを確認した.

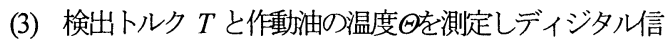
号処理器を用いて流量を実時間演算するシステムを構 築した. トルクと油温を同時に変化させて実験を行い， 算出した流量は基淮流量計で計測した流量とほぼ一致 することを明らかにした。

（4）サーボ弁を用いて周波数学答実験を行い，本流量計の 動特性を検証した，その結果，振幅比がー3dB となる 周波数は $f=7 \mathrm{~Hz}$ 付近であり, 高店答性能を有寸る 2 台 の市販流量計とほほ同等であることを確認した.

\section{文献}

(1) The Japan Society of Mechanical Engineers ed., JSME Date Book : Flow Measurements, (2000), p.165-173, The Japan Society of Mechanical Engineers.

(2) Komiya, K., Measurements of Flow quantity (in Japanese), (2005), Asakura Publishing Co. Ltd..

(3) The Japan Society of Mechanical Engineers ed., JSME Mechanical Engineers Handbook Fundamentals $\alpha 4$ : Fluids Engineering, (2006), The Japan Society of Mechanical Engineers.

(4) The Japan Hydraulics and Pneumatics Society ed., Hydraulics and Pneumatics Handbook, New edition, (1989) , p.115-147. Ohmsha Ltd..

(5) Nishiumi, T., Ichiyanagi, T. and Konami S., A Study on the Flowmeter Utilizing Lateral Fluid Force Acted on a Stationary Tapered Body in a Fluid Line (Static Analytical Characteristics and Measurement Evaluation), Journal of Japan Fluid Power System Society, Vol.35, No.4, (2004), P.63-69.

(6) Blackburn, J.F., Lateral Forces on Hydraulic Pistons, Transactions of ASME, Vol. 75, (1953), p. $1175-1180$

(7) Konami, S., Nishiumi, T., Hydraulic Control Systems, (1999), p.46-60, Tokyo Denki University Press.

(8) Ichiyanagi, T., Nishiumi, T., and Kuramoto, T., CFD analysis of torque detected type flow meter, Proceedings of the 2nd International Conference on Computational Methods in Fluid Power Technology, B-02, (2006-8). 